\title{
Are nitrate production and retention processes in subtropical acidic forest soils responsive to ammonium deposition?
}

\author{
Wenlong Gao ${ }^{\text {a, b }}$, Liang Kou ${ }^{\text {a, b }}$, Hao Yang ${ }^{a}$, Jinbo Zhang ${ }^{c}$, Christoph Müller ${ }^{\text {d, e }}$, \\ Shenggong $\mathrm{Li}^{\text {a, ** }}$ \\ ${ }^{a}$ Key Laboratory of Ecosystem Network Observation and Modeling, Institute of Geographical Sciences and Natural Resources Research, University of Chinese \\ Academy of Sciences, Chinese Academy of Sciences, Beijing, 100101, China \\ ${ }^{\mathrm{b}}$ University of Chinese Academy of Sciences, Beijing, 100049, China \\ ' School of Geography Sciences, Nanjing Normal University, Nanjing, 210047, China \\ d Department of Plant Ecology, Justus-liebig University Giessen, Heinrich Buff Ring 26, 35392, Giessen, Germany \\ e School of Biology and Environmental Science and Earth Institute, University College Dublin, Belfield, Ireland
}

\section{A R T I C L E I N F O}

\section{Article history:}

Received 5 December 2015

Received in revised form

3 June 2016

Accepted 5 June 2016

Available online 11 June 2016

\section{Keywords:}

$\mathrm{N}$ deposition

Gross N transformations

DNRA

${ }^{15} \mathrm{~N}$ tracing model

Acid soil of subtropical forest

\begin{abstract}
A B S T R A C T
Changes in soil $\mathrm{N}$-cycling and retention processes in subtropical/tropical acidic forest ecosystems under anthropogenic $\mathrm{N}$ inputs are not well understood. We conducted a laboratory ${ }^{15} \mathrm{~N}$ tracing study on an acid soil (pH values: 4.6 to 5.0) from a subtropical forest fertilized for more than 2.5 years at a rate of 0,40 , and $120 \mathrm{~kg} \mathrm{NH}_{4} \mathrm{Cl}-\mathrm{N} \mathrm{ha}^{-1} \mathrm{yr}^{-1}$, respectively. To get a better resolution of mechanistic changes in soil $\mathrm{N}$ cycling and retention processes under $\mathrm{NH}_{4}^{+}$additions, we used a conceptual ${ }^{15} \mathrm{~N}$ tracing model to quantify process-specific and pool-specific $\mathrm{N}$ transformation rates in soils. Gross $\mathrm{N}$ mineralization rates decreased at high $\mathrm{NH}_{4}^{+}$additions, which were paralleled by a reduction in fungal biomass and mineralization of recalcitrant organic N. Gross $\mathrm{NH}_{4}^{+}$immobilization rates did not show a change with increasing $\mathrm{NH}_{4}^{+}$ additions. Interestingly, soil $\mathrm{NO}_{3}^{-}$production (heterotrophic, autotrophic, and gross nitrification) and retention $\left(\mathrm{NO}_{3}^{-}\right.$immobilization and dissimilatory nitrate reduction to ammonium) showed insensitivity to increasing additions of $\mathrm{NH}_{4}^{+}$. The mechanisms behind the lack of response of heterotrophic nitrification were unclear, but possibly related to the absence of significant changes in soil C: $\mathrm{N}$ ratio and soil acidity under increased $\mathrm{NH}_{4}^{+}$additions. Because of the low autotrophic nitrification potential and the lack of $\mathrm{NH}_{4}^{+}$limitation to autotrophic nitrifiers, autotrophic nitrification was unresponsive to $\mathrm{NH}_{4}^{+}$additions. $\mathrm{NO}_{3}^{-}$immobilization rates appeared to be controlled by the $\mathrm{NO}_{3}^{-}$produced from heterotrophic nitrification, as indicated by the positive relationship between $\mathrm{NO}_{3}^{-}$immobilization and heterotrophic nitrification $\left(R^{2}=0.59, p=0.015\right)$, thus showing a lack of a change under increased $\mathrm{NH}_{4}^{+}$additions. DNRA seemed to be inherently less responsive to environmental changes such as $\mathrm{NH}_{4}^{+}$deposition. Our work demonstrates that enhanced $\mathrm{NH}_{4}^{+}$deposition has a low potential to stimulate soil $\mathrm{NO}_{3}^{-}$production and weaken soil retention of $\mathrm{NO}_{3}^{-}$in this, and perhaps other subtropical/tropical acidic forest ecosystems.
\end{abstract}

(ङ) 2016 Elsevier Ltd. All rights reserved.

\section{Introduction}

Nitrogen $(\mathrm{N})$ mineralization is at least a two-step process: the depolymerization of $\mathrm{N}$-containing soil polymers into organic $\mathrm{N}$ containing monomers (amino acids, amino sugars, nucleic acids, etc.) and subsequent ammonification (Schimel and Bennett, 2004). The depolymerization step, critical in $\mathrm{N}$ cycling, is controlled by extracellular enzymes which are often produced by fungi (Jones

\footnotetext{
* Corresponding author.

E-mail address: lisg@igsnrr.ac.cn (S. Li).
}

et al., 2004; Schimel and Bennett, 2004). Ammonium ( $\left.\mathrm{NH}_{4}^{+}\right)$supplied by $\mathrm{N}$ mineralization strongly influences $\mathrm{NH}_{4}^{+}$immobilization (Booth et al., 2005). With high rates of $\mathrm{N}$ mineralization and ample $\mathrm{NH}_{4}^{+}$availability, autotrophic nitrification rates in many subtropi$\mathrm{cal} /$ tropical acidic forest soils (soil $\mathrm{pH}<5.0$ ) remain low (Huygens et al., 2008; Zhang et al., 2013), indicating that autotrophic nitrification rates in these acidic soils might not be controlled by $\mathrm{NH}_{4}^{+}$ availability (Zhao et al., 2007). In subtropical/tropical acid forest soils (soil pH: <5.0) with high soil C: $\mathrm{N}$ ratios $(>15.0)$ and fungal biomass, nitrification tends to be heterotrophic, and microbial immobilization of nitrate $\left(\mathrm{NO}_{3}^{-}\right)$dominates over dissimilatory 
nitrate reduction to ammonium (DNAR) in $\mathrm{N}$ retention (Huygens et al., 2008; Zhang et al., 2013; Zhu et al., 2013). Forest soils exhibiting high rates of heterotrophic nitrification generally have higher $\mathrm{NO}_{3}^{-}$immobilization rates, but this is not the case for forest soils with high rates of autotrophic nitrification (Huygens et al., 2007, 2008; Zhang et al., 2013; Zhu et al., 2013), suggesting that $\mathrm{NO}_{3}^{-}$immobilization and heterotrophic nitrification might be functionally linked in forest soils. Many studies document the occurrence of DNAR in tropical/subtropical forest soils, a potential $\mathrm{N}$ conservation mechanism that redirects $\mathrm{NO}_{3}^{-}$flow towards $\mathrm{NH}_{4}^{+}$ (Silver et al., 2001, 2005; Rütting et al., 2008). Huygens et al. (2008) pointed out that DNRA also depends directly on heterotrophic nitrification for substrate generation.

Subtropical/tropical forest ecosystems are projected to receive enhanced N deposition (Galloway et al., 2008; Liu et al., 2013), but changes in the processes, rates and controls of soil N-cycling in these ecosystems under anthropogenic $\mathrm{N}$ inputs are less well understood (Silver et al., 2005; Corre et al., 2010; Cusack et al., 2011; Baldos et al., 2015; Gao et al., 2015). For example, Corre et al. (2010) reported that during 9 years of $\mathrm{N}$ addition to an oldgrowth lowland forest with net primary production not limited by $\mathrm{N}$, microbial biomass decreased with increased soil acidity, but gross $\mathrm{N}$ mineralization rates increased. Although this increase of gross $\mathrm{N}$ mineralization was attributed to increased substrate quality, no direct evidences were provided (e.g. which organic N pool was affected in the soil). Despite widespread evidence for $\mathrm{N}$ deposition-induced nonlinear increase in net production and loss of $\mathrm{NO}_{3}^{-}$from subtropical/tropical soils (Silver et al., 2005; Corre et al., 2010; Baldos et al., 2015), it remains uncertain to what extent this increase results from stimulation of either autotrophic or heterotrophic nitrifiers, or from the saturation of $\mathrm{N}$ uptake by plants, heterotrophic microbes, mycorrhizae, and abiotic reactions (Perakis et al., 2005). The low autotrophic nitrification potential of subtropical/tropical acidic forest soils suggests that autotrophic nitrification in these soils is unlikely to be stimulated by $\mathrm{N}$ deposition. Moreover, soil C: N ratio (Templer et al., 2012) and fungal biomass (Frey et al., 2004; Demoling et al., 2008) are often observed to decrease with $\mathrm{N}$ deposition. This indicates that $\mathrm{N}$ deposition will not stimulate heterotrophic nitrification to affect $\mathrm{NO}_{3}^{-}$production and retention in subtropical/tropical acidic forest soils.

Determination of soil gross $\mathrm{N}$ transformation rates can provide information on the mechanisms of not only the $\mathrm{N}$ cycle of the soil, but also its $\mathrm{N}$ status. It has been shown that $\mathrm{N}$-saturated forest soil is generally characterized by an uncoupled microbial $\mathrm{N}$ cycle; $\mathrm{NH}_{4}^{+}$ and $\mathrm{NO}_{3}^{-}$immobilization rates are lower than or do not keep pace with gross $\mathrm{N}$ mineralization and nitrification rates, respectively (Corre et al., 2003, 2007, 2010; Venterea et al., 2004).

In this study, we conducted a laboratory ${ }^{15} \mathrm{~N}$ tracing study with soil $(0-10 \mathrm{~cm})$ from a subtropical forest plantation, which was fertilized for more than 2.5 years at a rate of 0,40 , and $120 \mathrm{~kg}$ $\mathrm{NH}_{4} \mathrm{Cl}-\mathrm{N}$ ha $^{-1} \mathrm{yr}^{-1}$, respectively. To get a better solution of soil $\mathrm{N}$ cycling and retention processes, we used a process-based ${ }^{15} \mathrm{~N}$ model to quantify process-specific and pool-specific $\mathrm{N}$ transformation rates in soils (Müller et al., 2007; Rütting and Müller, 2007). The main objectives were to determine if and how gross rates of soil $\mathrm{N}$ transformations ( $\mathrm{N}$ mineralization, $\mathrm{NH}_{4}^{+}$immobilization, gross nitrification, autotrophic nitrification, heterotrophic nitrification, $\mathrm{NO}_{3}^{-}$immobilization and DNRA) would be altered by increasing $\mathrm{NH}_{4}^{+}$additions. We hypothesized that $\mathrm{NH}_{4}^{+}$additions would not stimulate soil $\mathrm{NO}_{3}^{-}$production (heterotrophic, autotrophic and gross nitrification) and weaken soil retention of $\mathrm{NO}_{3}^{-}\left(\mathrm{NO}_{3}^{-}\right.$ immobilization and DNRA).

\section{Materials and methods}

\subsection{Site description, experimental design and sampling}

The chronic $\mathrm{N}$-fertilization experiment site was established in November 2011 in a 28-year-old subtropical slash pine (Pinus elliottii) plantation at the Qianyanzhou Experimental Station of Red Soil and Hilly Land, Chinese Academy of Sciences (CAS), Jiangxi province, southeastern China ( $115^{\circ} 03^{\prime} 29.2^{\prime \prime}$ E, 26 $44^{\prime} 29.1^{\prime \prime} \mathrm{N}, 102 \mathrm{~m}$ a.s.l.). The study site has been described in detailed by Wang et al. (2015). The dominant understory species are Woodwardia japonica, Loropetalum chinense and Dicranopteris dichotoma (Wang et al., 2012). The soil is classified as Typical Dystrudepts Udepts Inceptisols (USDA Soil Taxonomy), derived from weathered red sandstone and mud stone. The study area belongs to subtropical monsoon climate, with mean annual temperature and mean annual precipitation of $17.9^{\circ} \mathrm{C}$ and $1475 \mathrm{~mm}$, respectively (Wen et al., 2010). Soil characteristics in the top $0-10 \mathrm{~cm}$ were presented in Table 1 . The mean (2008-2011) precipitation deposition of dissolved inorganic $\mathrm{N}$ (DIN) was $12.6 \pm 1.5 \mathrm{~kg} \mathrm{~N} \mathrm{ha}^{-1} \mathrm{a}^{-1}$, with a $\mathrm{NH}_{4}^{+}-\mathrm{N} / \mathrm{NO}_{3}^{-}-\mathrm{N}$ ratio of 1.9:1 (Zhan et al., 2014).

To explore the nonlinear response of microbial $\mathrm{N}$ cycling to $\mathrm{N}$ deposition, starting in May 2012 we fertilized $20 \mathrm{~m} \times 20 \mathrm{~m}$ plots at the rates of $0,40 \mathrm{~kg} \mathrm{~N} \mathrm{ha}^{-1} \mathrm{yr}^{-1}$ and $120 \mathrm{~kg} \mathrm{~N} \mathrm{ha}^{-1} \mathrm{yr}^{-1}$ in a randomized block design (each with three replicates, totaling 9 plots). $\mathrm{N}$ was added as ammonium chloride $\left(\mathrm{NH}_{4} \mathrm{Cl}\right)$. The three blocks, laid out across a-40 ha, had at least a $10 \mathrm{~m}$ buffer zone between any two plots within each block. N solutions were sprayed monthly to the forest floors with a backpack sprayer. Each month, each fertilized plot received $30 \mathrm{~L}$ of $\mathrm{NH}_{4} \mathrm{Cl}$ solutions, and each control plot received $30 \mathrm{~L}$ of water without fertilizer.

The low $\mathrm{N}$ treatment was to simulate a future increase in the atmospheric $\mathrm{N}$ deposition by 3 -fold, corresponding to the annual bulk deposition rates in the subtropical region of China (>22.2-35 $\mathrm{kg} \mathrm{N} \mathrm{ha}^{-1} \mathrm{yr}^{-1}$ ) (Liu et al., 2013; Jia et al., 2014), and the level of low $\mathrm{N}$ addition to subtropical/tropical forest ecosystems (50 kg N ha ${ }^{-1} \mathrm{yr}^{-1}$ ) (Hall and Matson, 1999; Mo et al., 2008; Baldos et al., 2015). The high $\mathrm{N}$ treatment was to stimulate $\mathrm{N}$-enriched conditions, exposing soil microbes to abrupt environmental changes to observe the direction of changes in soil N-cycling (Corre et al., 2010). The high $\mathrm{N}$ treatment level at our site, however, was similar to that in other subtropical/tropical forests (100-150 $\mathrm{kg} \mathrm{N} \mathrm{ha}^{-1} \mathrm{yr}^{-1}$ ) (Hall and Matson, 2003; Mo et al., 2008; Corre et al., 2010).

In late November 2014 (roughly 2.5 years after $\mathrm{N}$ addition), 8 samples per plot were collected from the top $0-10 \mathrm{~cm}$ soil using a PVC tube (inner diameter of $7 \mathrm{~cm}$; length of $15 \mathrm{~cm}$ ) after removing the thin litter layer. Soil samples were composited by plot, sieved (2 $\mathrm{mm})$, homogenized, and subsequently divided into two subsamples: one for analysis of soil properties ( $400 \mathrm{~g}$ ), and another for laboratory ${ }^{15} \mathrm{~N}$ tracing experiment $(800 \mathrm{~g})$. The ${ }^{15} \mathrm{~N}$ tracing experiment was carried out within two weeks, and soil samples were stored at $4{ }^{\circ} \mathrm{C}$ before analyses at the Jiangsu Key Laboratory of Environmental Change and Ecological Construction, School of Geography Sciences, Nanjing Normal University.

\subsection{Soil properties}

Soil moisture, total $\mathrm{C}$, total $\mathrm{N}, \mathrm{pH}, \mathrm{NH}_{4}^{+}$and $\mathrm{NO}_{3}^{-}$were determined (Table 1). Soil moisture was measured by drying the soil subsamples at $105^{\circ} \mathrm{C}$ for $48 \mathrm{~h}$. Total $\mathrm{C}$ and $\mathrm{N}$ contents were analyzed by an elemental analyzer (Europa Scientific Integra, UK) using airdried, finely ground soil. Soil $\mathrm{pH}$ was determined in a soil (airdried soil): water ratio of $1: 2.5$ by a DMP- $2 \mathrm{mV} / \mathrm{pH}$ detector (Quark Ltd., Nanjing, China). Soil $\mathrm{NH}_{4}^{+}$and $\mathrm{NO}_{3}^{-}$were extracted with $2 \mathrm{M}$ 
Table 1

Soil properties at $0-10 \mathrm{~cm}$ depth after 2.5 years of $\mathrm{NH}_{4}^{+}$addition.

\begin{tabular}{|c|c|c|c|c|c|c|}
\hline $\mathrm{NH}_{4}^{+}$addition & Soil pH 1:2.5 $\left(\mathrm{H}_{2} \mathrm{O}\right)$ & Soil $\mathrm{NH}_{4}^{+} \mathrm{mg} \mathrm{N} \mathrm{kg}^{-1}$ soil & Soil $\mathrm{NO}_{3}^{-} \mathrm{mg} \mathrm{N} \mathrm{kg}^{-1}$ soil & Soil C g C kg ${ }^{-1}$ soil & Soil $\mathrm{N} \mathrm{g} \mathrm{N} \mathrm{kg}^{-1}$ soil & Soil C: $\mathrm{N}$ ratio \\
\hline Control & $5.0 \pm 0.2$ & $11.7 \pm 2.1$ & $8.3 \pm 1.0$ & $14.5 \pm 0.5$ & $0.9 \pm 0.1$ & $16.3 \pm 1.9$ \\
\hline Low $\mathrm{N}$ & $4.6 \pm 0.0$ & $10.3 \pm 1.4$ & $9.7 \pm 1.4$ & $14.4 \pm 2.7$ & $0.9 \pm 0.2$ & $16.5 \pm 0.5$ \\
\hline High N & $4.7 \pm 0.3$ & $10.9 \pm 1.7$ & $10.5 \pm 1.6$ & $12.2 \pm 2.7$ & $0.8 \pm 0.2$ & $15.5 \pm 1.0$ \\
\hline
\end{tabular}

Values are means with standard errors (SE; $n=3$ ).

$\mathrm{KCl}$ at a soil/extractant ratio of 1: 5 after shaking for $60 \mathrm{~min}$ at $250 \mathrm{rpm}$ and $25^{\circ} \mathrm{C}$, and the concentrations of $\mathrm{NH}_{4}^{+}$and $\mathrm{NO}_{3}^{-}$were assayed with a continuous-flow analyzer (Skalar, Breda, the Netherlands).

\section{3. ${ }^{15} \mathrm{~N}$ tracing experiment}

There were two ${ }^{15} \mathrm{~N}$ treatments (each with three replications), of which either ammonium $\left({ }^{15} \mathrm{NH}_{4} \mathrm{NO}_{3}\right)$ or nitrate $\left(\mathrm{NH}_{4}^{15} \mathrm{NO}_{3}\right)$ were labeled with ${ }^{15} \mathrm{~N}$ at 10 at.\% excess. For each plot, the sieved soil was placed in four sets of conical flasks (six conical flasks per set, three of the six conical flasks for ${ }^{15} \mathrm{NH}_{4} \mathrm{NO}_{3}$ labeling, and the remaining three for $\mathrm{NH}_{4}^{15} \mathrm{NO}_{3}$ labeling; each conical flask containing fresh soil with the equivalent of $20 \mathrm{~g}$ of dry soil) (see supporting information, Fig. S1). After sealing with parafilm with five pin holes for gas exchange, the conical flasks were preincubated in the dark for $24 \mathrm{~h}$ at $25{ }^{\circ} \mathrm{C}$. After pre-incubation, three $\mathrm{ml}$ of ${ }^{15} \mathrm{NH}_{4} \mathrm{NO}_{3}$ or $\mathrm{NH}_{4}^{15} \mathrm{NO}_{3}$ solution was added to each conical flask at a rate of $2.86 \mu \mathrm{mol} \mathrm{N} \mathrm{g}{ }^{-1}$ dry soil $\left(20 \mu \mathrm{g} \mathrm{NH}_{4}^{+}-\mathrm{N} \mathrm{g}^{-1}\right.$ dry soil and $20 \mu \mathrm{g} \mathrm{NO}_{3}^{-}-\mathrm{N} \mathrm{g}^{-1}$ dry soil $)$. The conical flask was incubated in the dark for $144 \mathrm{~h}$ at $25^{\circ} \mathrm{C}$ after adjusting the soil to $60 \%$ water holding capacity (WHC) and sealing with parafilm (with five pin holes for air exchange). Soil extractions were carried out at $0.5,48,96$, and $144 \mathrm{~h}$ after label addition to determine the concentrations and isotopic compositions of $\mathrm{NH}_{4}^{+}$ and $\mathrm{NO}_{3}^{-}$. A detailed description of laboratory ${ }^{15} \mathrm{~N}$ tracing study on each soil sample can be found in Fig. S1 (see supporting information).

It should be noted that field treatment effects may be somewhat masked by laboratory additions of $\mathrm{NH}_{4} \mathrm{NO}_{3}$. $\mathrm{N}$ was added to the plantation floor in the form of $\mathrm{NH}_{4}^{+}$only. However, we used either ${ }^{15} \mathrm{NH}_{4} \mathrm{NO}_{3}$ or $\mathrm{NH}_{4}^{15} \mathrm{NO}_{3}$ as $\mathrm{N}$ tracer, and thus there may be an additive effect of $\mathrm{NH}_{4}^{+}$and $\mathrm{NO}_{3}^{-}$on microbial cycling of $\mathrm{N}$ in the soil. Actually, we addressed this concern by taking the $1: 1$ ratio of $\mathrm{NH}_{4}^{+}$ to $\mathrm{NO}_{3}^{-}$in field samples into consideration (Table 1). Previous studies have suggested that cold storage, soil sieving and laboratory incubation all would produce effects on microbial cycling of $\mathrm{N}$ (Johnson et al., 2005; Huygens et al., 2007; Arnold et al., 2008). However, laboratory measurements of gross $\mathrm{N}$ transformations allow identifying the direction of the change in in-situ $\mathrm{N}$ transformations in treatments (Paterson, 2003).

Concentrations of $\mathrm{NH}_{4}^{+}$and $\mathrm{NO}_{3}^{-}$were determined using methods described above. The isotopic compositions of $\mathrm{NH}_{4}^{+}$and $\mathrm{NO}_{3}^{-}$were determined using an automated $\mathrm{C}-\mathrm{N}$ analyzer coupled to an isotope ratio mass spectrometer (Europa Scientific Integra, UK). For isotopic analysis, $\mathrm{NH}_{4}^{+}$and $\mathrm{NO}_{3}^{-}$were separated by distillation with MgO and Devarda's alloy (Zhang et al., 2009, 2012b, 2013).

\section{4. ${ }^{15} \mathrm{~N}$ tracing model}

The ten simultaneously-occurring gross $\mathrm{N}$ transformations in the soil were quantified with a process-based ${ }^{15} \mathrm{~N}$ tracing model (Fig. 1) (Müller et al., 2007): $M_{\text {Nrec }}$, mineralization of recalcitrant organic $\mathrm{N}$ to $\mathrm{NH}_{4}^{+} ; M_{\text {Nlab}}$, mineralization of labile organic $\mathrm{N}$ to $\mathrm{NH}_{4}^{+}$; $I_{N H 4 \_N r e c}$, immobilization of $\mathrm{NH}_{4}^{+}$to recalcitrant organic-N; $I_{N H 4 \_N l a b}$, immobilization of $\mathrm{NH}_{4}^{+}$to labile organic-N; $R_{N H 4 a d s}$, release of adsorbed $\mathrm{NH}_{4}^{+} ; A_{N H 4}$, adsorption of $\mathrm{NH}_{4}^{+}$on cation exchange sites; $\mathrm{O}_{\mathrm{NH} 4}$, oxidation of $\mathrm{NH}_{4}^{+}$to $\mathrm{NO}_{3}^{-}$(autotrophic nitrification); $O_{\mathrm{Nrec}}$, oxidation of recalcitrant organic $\mathrm{N}$ to $\mathrm{NO}_{3}^{-}$(heterotrophic nitrification); $I_{\mathrm{NO} 3 \text { Nrec }}$, immobilization of $\mathrm{NO}_{3}^{-}$to recalcitrant organic $\mathrm{N}$; and $D_{\mathrm{NO}}$, dissimilatory $\mathrm{NO}_{3}^{-}$reduction to $\mathrm{NH}_{4}^{+}$. The transformation rates were calculated either by zero $\left(M_{N r e c}\right.$ and $\left.O_{N r e c}\right)$ or first-order $\left(M_{N l a b}, I_{N H 4 \_N r e c}, I_{N H 4 \_N l a b}, O_{N H 4}, I_{N O 3 \_N r e c}\right.$, and $\left.D_{N O 3}\right)$ kinetics. It should be noted that gaseous $\mathrm{N}$ losses and $\mathrm{N}$ leaching can not be simulated by this model. Based on available $\mathrm{N}$ cycling parameters, gross $\mathrm{N}$ mineralization $\left(M_{t o t}=M_{N l a b}+M_{N r e c}\right)$, gross nitrification/ gross $\mathrm{NO}_{3}^{-}$production $\left(\mathrm{O}_{\mathrm{NH} 4}+\mathrm{O}_{\mathrm{Nrec}}\right)$, gross $\mathrm{NH}_{4}^{+}$immobilization $\left(I_{N H 4}=I_{N H 4 \_N r e c}+I_{N H 4 \_N l a b}\right), \quad$ gross $\mathrm{NO}_{3}^{-}$immobilization $\left(I_{\mathrm{NO} 3}=I_{\text {NO3_Nrec }}\right)$, and gross $\mathrm{NO}_{3}^{-}$retention $\left(I_{\mathrm{NO} 3}+D_{\mathrm{NO} 3}\right)$ were calculated. The respective turnover rates of soil, labile and recalcitrant organic $\mathrm{N}$ was estimated: turnover rate of organic $\mathrm{N}=$ total $\mathrm{N} /$ $\left(M_{\text {tot }}+O_{\text {Nrec }}\right)$, turnover rate of labile organic $\mathrm{N}=$ labile organic $\mathrm{N} /$ $M_{\text {Nlab }}$, and turnover rate of recalcitrant organic $\mathrm{N}=$ recalcitrant organic $\mathrm{N} /\left(M_{\mathrm{Nrec}}+\mathrm{O}_{\mathrm{Nrec}}\right)$. In this study, labile and recalcitrant organic $\mathrm{N}$ were considered to equal $1 \%$ and $99 \%$ of soil organic $\mathrm{N}$ ( $\approx$ soil total N) (Jinbo Zhang, personal communication) due to the difficulty in separating soil organic $\mathrm{N}$ into different fractions to estimate the two conceptual organic N-pool sizes (Huygens et al., 2007). The data supplied to the model were the concentrations ( $\mu$ mol $\mathrm{N} \mathrm{g}^{-1}$ dry soil) and ${ }^{15} \mathrm{~N}$ excess (at. \% excess ${ }^{15} \mathrm{~N}$ ) of $\mathrm{NH}_{4}^{+}$and $\mathrm{NO}_{3}^{-}$(mean \pm standard deviations).

The model calculated gross $\mathrm{N}$ transformation rates by simultaneously optimizing the kinetic parameters for each individual process via minimizing the misfit between modeled and observed concentrations of $\mathrm{NH}_{4}^{+}$and $\mathrm{NO}_{3}^{-}$and their respective ${ }^{15} \mathrm{~N}$ enrichments. To obtain the most suitable model that was able to simulate

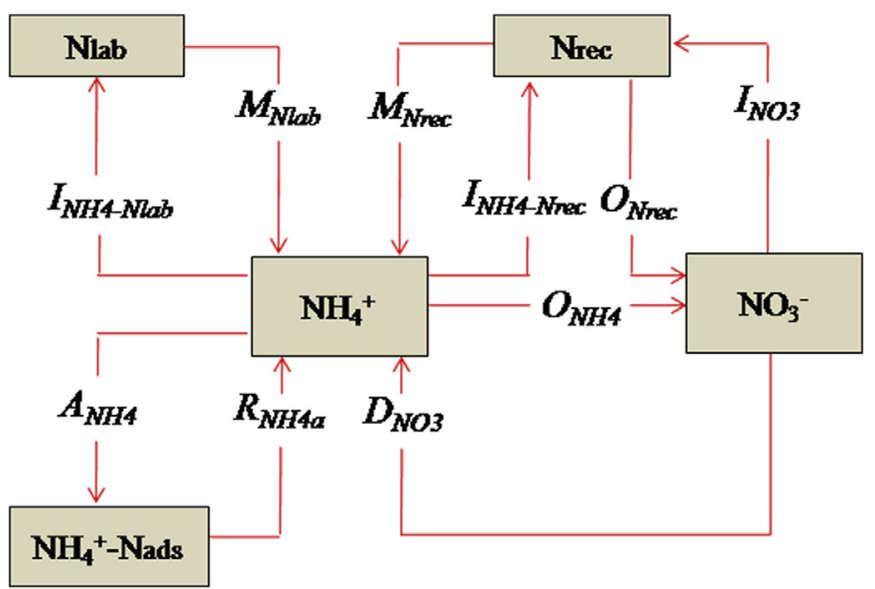

Fig. 1. Conceptual ${ }^{15} \mathrm{~N}$ tracing model (Müller et al., 2007). $\mathrm{N}_{\text {rec }}$, recalcitrant organic $\mathrm{N}$ $\mathrm{N}_{\text {lab }}$, labile organic $\mathrm{N} ; \mathrm{NH}_{4}^{+}$, ammonium; $\mathrm{NO}_{3}^{-}$, nitrate, $M_{N r e c}$, mineralization of recalcitrant organic $\mathrm{N}$ to $\mathrm{NH}_{4}^{+} ; M_{N l a b}$, mineralization of labile organic $\mathrm{N}$ to $\mathrm{NH}_{4}^{+} ; I_{N H 4}$ Nrec immobilization of $\mathrm{NH}_{4}^{+}$to recalcitrant organic-N; $I_{\mathrm{NH} 4} \mathrm{Nlab}$, immobilization of $\mathrm{NH}_{4}^{+}$to labile organic $\mathrm{N} ; R_{N H 4 a d s}$, release of adsorbed $\mathrm{NH}_{4}^{+} ; A_{N H 4}$, adsorption of $\mathrm{NH}_{4}^{+}$on cation exchange sites; $O_{N H 4}$, oxidation of $\mathrm{NH}_{4}^{+}$to $\mathrm{NO}_{3}^{-}$(autotrophic nitrification); $O_{\mathrm{Nrec}}$, oxidation of recalcitrant organic-N to $\mathrm{NO}_{3}^{-}$(heterotrophic nitrification); $I_{\mathrm{NO} 3 \mathrm{Nrec}}$, immobilization of $\mathrm{NO}_{3}^{-}$to recalcitrant organic $\mathrm{N}$; and $\mathrm{D}_{\mathrm{NO}}$, dissimilatory $\mathrm{NO}_{3}^{-}$reduction to $\mathrm{NH}_{4}^{+}$. 
the observed data, the number of possible $\mathrm{N}$ transformations, the possible kinetic settings of individual processes (zero/first-order kinetics/Michaelis-Menten kinetics) and $\mathrm{N}$ pools were varied and evaluated. The final model was identified based on Aikaike's information criterion (AIC) (the smallest AIC) (Cox et al., 2006). Initially, all parameters ( $\mathrm{N}$ pools and $\mathrm{N}$ transformations) from the conceptual model (Fig. 1) were included in the optimization run and the kinetic settings adjusted to reach an AIC as low as possible. Those parameters approaching zero were considered to not significantly improve the model fit and were excluded in the following step. In general, $\mathrm{N}$ transformations (e.g. $M_{N r e c}$ and $O_{N r e c}$ ) originating from large pool sizes are appropriately described by zero-order kinetics, while $\mathrm{N}$ transformations $\left(M_{\mathrm{Nlab}}, I_{\mathrm{NH} 4 \_N r e c}\right.$, $I_{\mathrm{NH} 4 \_N a b}, I_{\mathrm{NO}-\mathrm{Nrec}}$, and $D_{\mathrm{NO} 3}$ ) originating from small pool sizes are likely to follow first-order kinetics (Myrold and Tiedje, 1986). Michaelise-Menten kinetics, rather than zero- or first-order kinetics, could be more appropriate to describe $\mathrm{NH}_{4}^{+}$oxidation if the activity of nitrifying microbes undergoes a rapid change from non$\mathrm{NH}_{4}^{+}$limiting conditions (zero-order kinetics) to $\mathrm{NH}_{4}^{+}$limiting conditions (first-order kinetics) (Müller et al., 2007). A detailed description of stepwise modification in parameters and their kinetic settings to find the lowest AIC can be found in previous studies (Müller et al., 2007; Rütting and Müller, 2007; Inselsbacher et al., 2013). The model parameters were optimized with the Markov Chain Monte Carlo Metropolis algorithm (MCMC-MA), which has been described in detail by Müller et al. (2007). To get a better resolution of soil processes, and in line with previous studies, soil organic $\mathrm{N}$ pool was conceptually divided into two fractions, a labile and a recalcitrant pool (Müller et al., 2007; Inselsbacher et al., 2013; Zhang et al., 2013). The initial (i.e. $t=0$ ) pool sizes of mineral $\mathrm{N}\left({ }^{14} \mathrm{~N}\right.$ and $\left.{ }^{15} \mathrm{~N}\right)$ were estimated based on Müller et al. (2004). In brief, the initial concentrations of $\mathrm{NH}_{4}^{+}$and $\mathrm{NO}_{3}^{-}$were obtained by extrapolating the data at $t=0.5 \mathrm{~h}$ and $24 \mathrm{~h}$ ( $48 \mathrm{~h}$ for the incubation experiment) back to $t=0 \mathrm{~h}$. The initial values of the $\mathrm{NH}_{4 \text { ads }}$ were measured as the difference between applied $\mathrm{NH}_{4}^{+}$and the initial concentrations of $\mathrm{NH}_{4}^{+}$. The optimization procedure samples the probability density function (PDF) for each process, from which the average and standard deviation of each process is calculated. For $\mathrm{N}$ transformations following first-order kinetics, average gross rates were calculated by integrating the gross rates over the entire experimental period, divided by the incubation time (Müller et al., 2007; Inselsbacher et al., 2013). The gross $\mathrm{N}$ transformation rates were expressed in units of $\mathrm{mg} \mathrm{N} \mathrm{kg}^{-1}$ dry soil $\mathrm{d}^{-1}$. The MCMC-MA routine is programmed in the software Matlab (Version 7.2, The Math Works Inc.), which calls models that are separately set up in Simulink (Version 6.4, The Math Works Inc.).

\subsection{Data analysis}

All the data were tested for normality (Shapiro-Wilk test) and homogeneity of variance before analyses (Levene-test). If preconditions of ANOVA were not met, we employed the KruskalWallis $H$ test with paired comparisons for testing differences among treatments. Data showing normal distribution and homogeneity were tested by the one-way analysis of variance (ANOVA) with Least Significant Difference (LSD) test to compare the differences between treatments. $\mathrm{N}$ dose was set as main effects. To explore the potential relationships between gross $\mathrm{N}$ transformation rates and soil characteristics, and among $\mathrm{N}$ transformation rates, linear regression and Spearman's rank correlation were performed for parameters that showed normal and non-normal distributions, respectively, with experimental plots ( 9 plots) as the experimental unit. We tested for significant differences at $\alpha=0.10$. All analyses were conducted using SPSS version 20.0 (IBM Co., Armonk, NY, USA).

\section{Results}

\subsection{Dynamics of $N$ pool sizes and ${ }^{15} \mathrm{~N}$ enrichment}

The stimulated and observed concentrations and isotopic enrichment matched well, and were generally within the range of the observed mean \pm sd (Fig. 2 and Figs. $\mathrm{S}_{2}-10$ ). $\mathrm{NH}_{4}^{+}$concentrations increased with incubation time in all the soils, with a much lower increase rate in the high $\mathrm{N}$-addition plots (Figs. $\mathrm{S} 2-10$; a). Compared to the control plots, $\mathrm{NO}_{3}^{-}$concentrations increased at a slightly higher rate in plots receiving $\mathrm{N}$ addition (Figs. $\mathrm{S} 2-10$; b). The dilution of ${ }^{15} \mathrm{~N}$ in the $\mathrm{NH}_{4}^{+}$or $\mathrm{NO}_{3}^{-}$pools when the $\mathrm{N}$ pool was labeled indicated an inflow of unlabeled $\mathrm{NH}_{4}^{+}$or $\mathrm{NO}_{3}^{-}$into the labeled $\mathrm{N}$ pool (Figs. S2-10). The very small change in ${ }^{15} \mathrm{~N}$ of the $\mathrm{NH}_{4}^{+}$pool under $\mathrm{NH}_{4}^{15} \mathrm{NO}_{3}$ labeling suggested that DNRA rates were negligible (Figs. S2-10; c). The slow increase in ${ }^{15} \mathrm{~N}$ of the $\mathrm{NO}_{3}^{-}$pool under ${ }^{15} \mathrm{NH}_{4} \mathrm{NO}_{3}$ labeling indicated low autotrophic nitrification rates (Figs. S2-10; d).

\subsection{Mineralization-immobilization turnover}

Gross $N$ mineralization rates $\left(M_{t o t}\right)$ in the high N-addition plots were $28.6 \%$ lower $(p=0.055)$, while showed no significant changes in the low $\mathrm{N}$-addition plots $(p=0.938)$ compared to the control plots $\left(3.72 \pm 0.14 \mathrm{mg} \mathrm{N} \mathrm{kg}^{-1}\right.$ soil d ${ }^{-1}$ ) (Fig. 3). $\mathrm{NH}_{4}^{+}$was produced in roughly equal proportion from mineralization of recalcitrant $\left(M_{N r e c}: 43-52 \%\right)$ and labile $\left(M_{N l a b}: 48-57 \%\right)$ organic N (Fig. 4). Mineralization of labile organic $\mathrm{N}$ was not significantly different across treatments. However, mineralization of recalcitrant organic $\mathrm{N}\left(M_{\text {Nrec }}\right)$ was $42.8 \%$ lower in the high $\mathrm{N}$-addition plots than in the control plots $(p=0.095)$. The main fate for the $\mathrm{NH}_{4}^{+}$produced was $\mathrm{NH}_{4}^{+}$immobilization $\left(I_{N H 4} / M_{\text {tot }} ; 72.6-73.7 \%\right)$, rather than $\mathrm{NH}_{4}^{+}$ oxidation $\left(\mathrm{O}_{\mathrm{NH} 4} / \mathrm{M}_{\text {tot }} ; 2.7-6.3 \%\right)$ (Fig. 3). Gross $\mathrm{NH}_{4}^{+}$immobilization rates $\left(I_{N H 4}\right)$ did not differ significantly across treatments. A higher proportion of the $\mathrm{NH}_{4}^{+}$produced was immobilized into labile $\left(I_{N H 4 \_N l a b} / M_{t o t} ; \quad 40.3-51.8 \%\right)$ than recalcitrant $\left(I_{N H 4 \_N r e c} / M_{t o t}\right.$; 20.4-33.4\%) organic N (Fig. 4). INH4_Nrec rates showed a trend of rise first and then a fall with increasing $\mathrm{NH}_{4}^{+}$additions (Fig. 4), while there were no significant differences in $I_{N H 4 \_N l a b}$ rates across treatments. The respective turnover rates of soil, labile and recalcitrant organic $\mathrm{N}$ did not differ significantly among treatments (Fig. 5).

Gross $\mathrm{NH}_{4}^{+}$immobilization rates in the control plots were not within the standard error limits around the mean of the corresponding gross $\mathrm{N}$ mineralization rates, and more so in plots receiving low $\mathrm{NH}_{4}^{+}$addition, and this was not the case in plots receiving high $\mathrm{NH}_{4}^{+}$addition (Fig. 3). However, net gross $\mathrm{NH}_{4}^{+}$production (gross $\mathrm{N}$ mineralization rates minus gross $\mathrm{NH}_{4}^{+}$immobilization rates) did not vary significantly among treatments (Fig. 3).

\section{3. $\mathrm{NO}_{3}^{-}$production and retention}

Heterotrophic $\left(O_{N r e c}, 79.8-91.6 \%\right)$ dominated over autotrophic $\left(\mathrm{O}_{\mathrm{NH} 4}, 8.4-20.2 \%\right)$ nitrification in $\mathrm{NO}_{3}^{-}$production. Autotrophic, heterotrophic, and gross nitrification rates did not differ significantly across treatments (Fig. 3). $25.6-55.0 \%$ of the $\mathrm{NO}_{3}^{-}$produced (gross nitrification) was immobilized into recalcitrant organic $\mathrm{N}$ $\left(I_{N O 3}\right)$, with $3.7-6.3 \%$ being converted into $\mathrm{NH}_{4}^{+}$via DNRA. $I_{N O 3}$, DNRA and gross $\mathrm{NO}_{3}^{-}$retention rates $\left(I_{\mathrm{NO}}+\right.$ DNRA) did not vary significantly across treatments (Fig. 3). Gross $\mathrm{NO}_{3}^{-}$immobilization rates in the control and $\mathrm{NH}_{4}^{+}$addition plots were not within the standard error limits around the mean of the corresponding gross nitrification rates (Fig. 3). Net gross $\mathrm{NO}_{3}^{-}$production rates (gross nitrification rates minus gross $\mathrm{NO}_{3}^{-}$immobilization rates) did not show an increasing trend with increasing $\mathrm{NH}_{4}^{+}$additions (Fig. 3). 

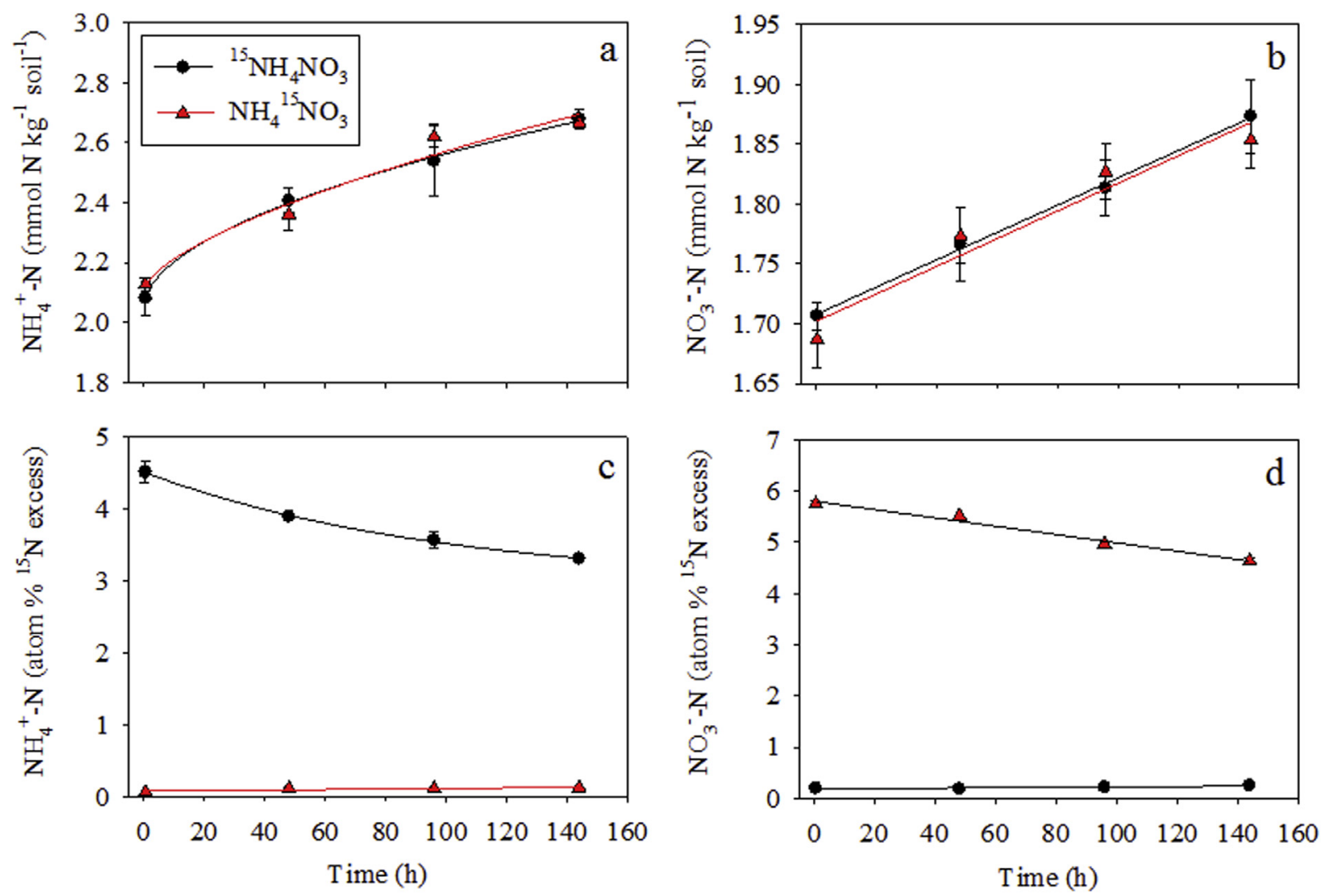

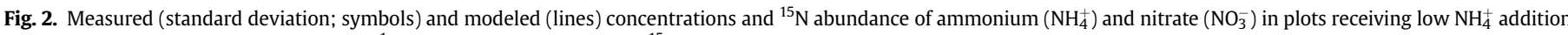
(block 1) after application of $40 \mathrm{mg} \mathrm{N} \mathrm{kg}{ }^{-1}$ soil as $\mathrm{NH}_{4} \mathrm{NO}_{3}$ at 10 atom $\%{ }^{15} \mathrm{~N}$ excess.

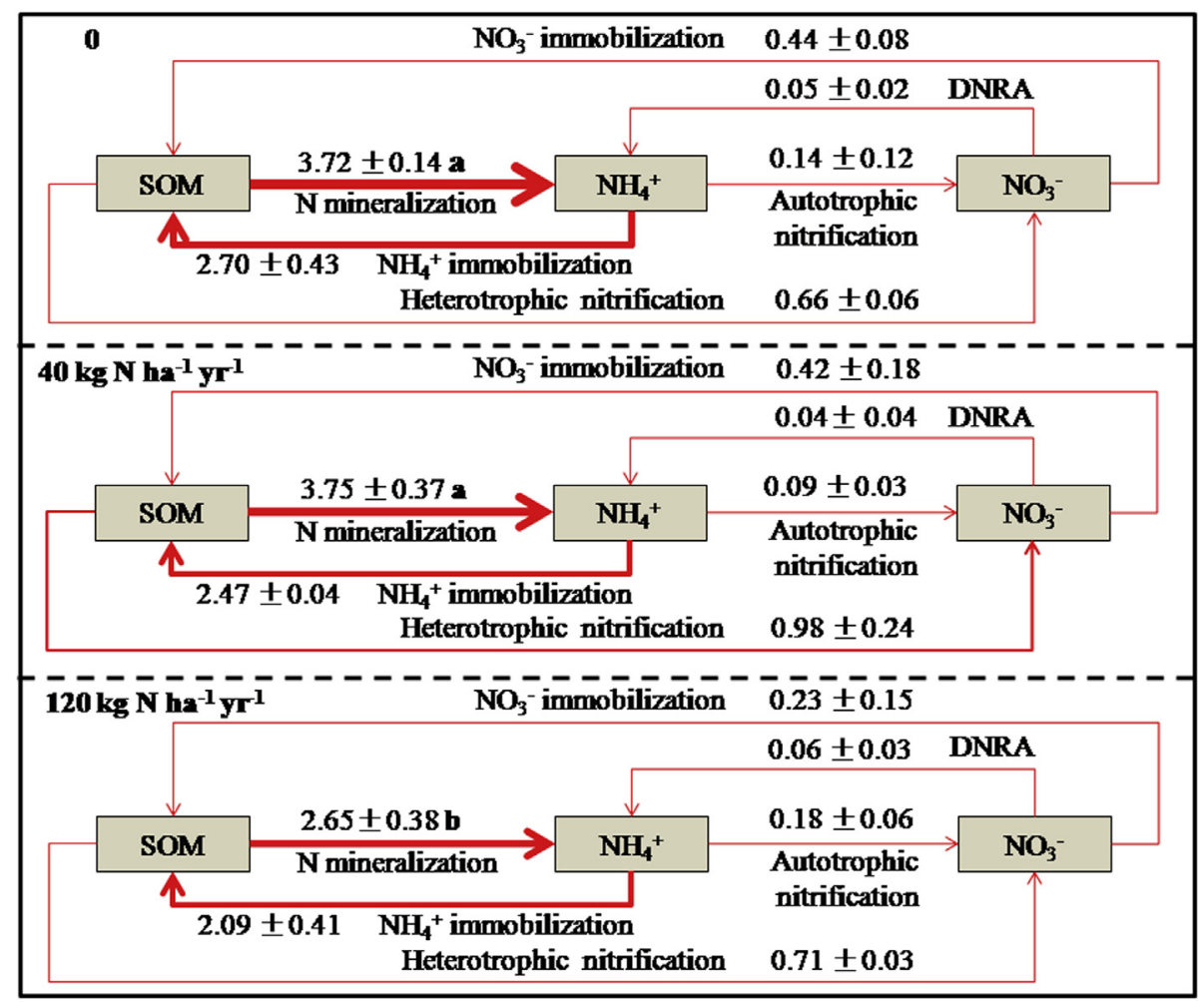

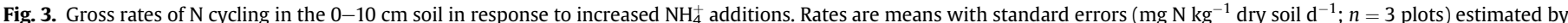

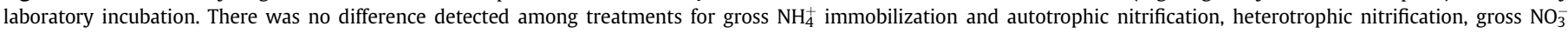
immobilization, and DNRA. For gross $\mathrm{N}$ mineralization, means followed by different letter indicated significance among treatments $(p<0.10)$. 


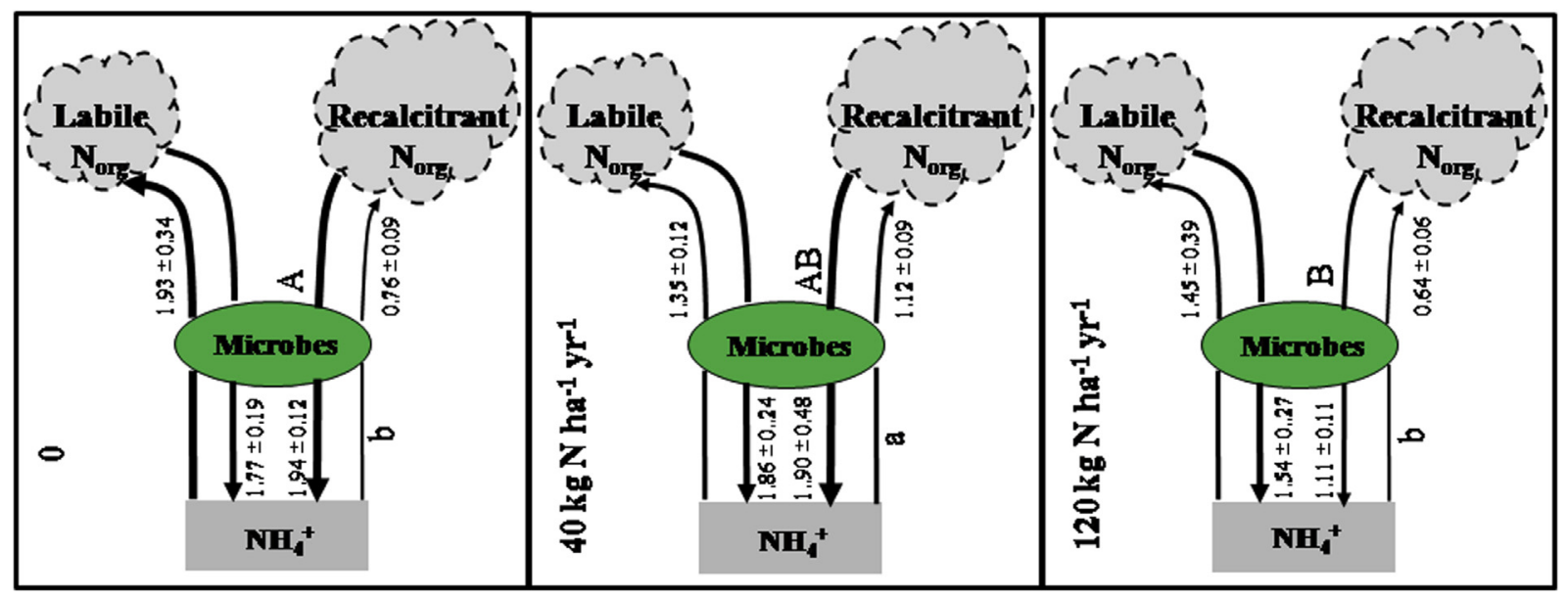

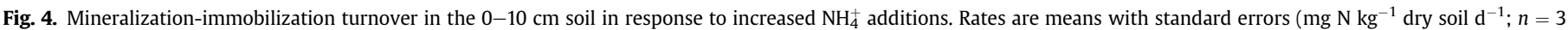

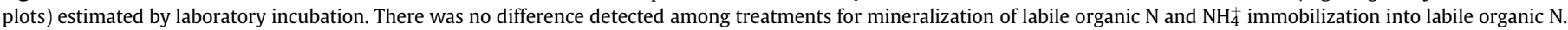

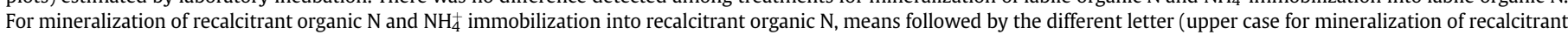
organic $\mathrm{N}$, and lower case for $\mathrm{NH}_{4}^{+}$immobilization into recalcitrant organic $\mathrm{N}$ ) indicated significance among treatments $(p<0.10)$.

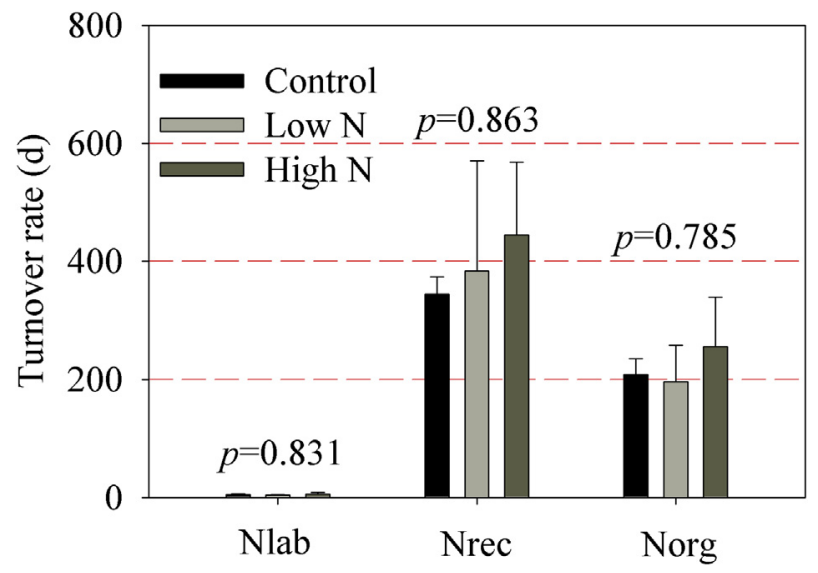

Fig. 5. The respective turnover rates of labile $\left(\mathrm{N}_{\text {lab }}\right)$, recalcitrant $\left(\mathrm{N}_{\mathrm{rec}}\right)$, and soil $\left(\mathrm{N}_{\mathrm{org}}\right)$ organic $\mathrm{N}$ under increased $\mathrm{NH}_{4}^{+}$additions. There were no treatments effects on the turnover rates of labile, recalcitrant, and soil organic $\mathrm{N}(p<0.10)$.

We did not find a significant correlation of heterotrophic nitrification to soil C: $\mathrm{N}$ ratio. However, there were some significant correlations among $\mathrm{N}$-cycling rates. $I_{\mathrm{NO} 3}$ rates were significantly and positively correlated to heterotrophic nitrification $\left(R^{2}=0.59\right.$, $p=0.015)$ and gross nitrification $\left(R^{2}=0.64, p=0.009\right)$, respectively. DNRA rates were significantly and negatively correlated to gross nitrification rates $\left(R^{2}=0.59, p=0.016\right)$.

\section{Discussion}

\subsection{The effects of $\mathrm{NH}_{4}^{+}$additions on mineralization-immobilization turnover}

Previous studies have indicated that SOM fractions (Swanston et al., 2004; Janssens et al., 2010; Cusack et al., 2011) and their associated mineralization-immobilization turnover (Corre et al., 2010; Zhang et al., 2012a; Koranda et al., 2014) respond differently to $\mathrm{N}$ deposition over time. Thus, in this study, we quantified two specific gross $\mathrm{N}$ mineralization rates and two specific gross $\mathrm{NH}_{4}^{+}$immobilization rates, related to either a rapid $\left(\mathrm{N}_{\text {lab }}\right)$ or a slower $\left(\mathrm{N}_{\mathrm{rec}}\right)$ turnover of organic $\mathrm{N}$ pool (Fig. 1). Mineralization of recalcitrant and labile organic $\mathrm{N}$ played an equal role in $\mathrm{NH}_{4}^{+}$production, and the $\mathrm{NH}_{4}^{+}$produced was preferentially immobilized into labile organic $\mathrm{N}$ (Fig. 4). We observed that compared to mineralization-immobilization turnover originating from labile organic $\mathrm{N}$ pool, $\mathrm{NH}_{4}^{+}$additions had more of an effect on mineralization-immobilization turnover originating from recalcitrant organic N pool, and that the effect is dose-dependant. However, the respective turnover rates of soil, labile and recalcitrant organic $\mathrm{N}$ were not significantly affected by increased $\mathrm{NH}_{4}^{+}$additions (Fig. 5).

Low $\mathrm{NH}_{4}^{+}$additions stimulated $\mathrm{NH}_{4}^{+}$immobilization into recalcitrant organic $\mathrm{N}$ ( $I_{N H 4}$ Nrec $)$ (Fig. 4). Although the increase in $I_{N H 4 \_N r e c}$ rates do not facilitate a rapid recycling of $\mathrm{NH}_{4}^{+}$(Zhang et al., 2012a), mineralization of recalcitrant organic N, gross $\mathrm{N}$ mineralization and gross $\mathrm{NH}_{4}^{+}$immobilization did not change at low $\mathrm{NH}_{4}^{+}$ additions. The increase of $\mathrm{NH}_{4}^{+}$immobilization into recalcitrant organic $\mathrm{N}$ indicates that microbial $\mathrm{N}$ demand increases at low $\mathrm{NH}_{4}^{+}$ additions (Rütting et al., 2010). At low $\mathrm{NH}_{4}^{+}$additions the increased $I_{N H 4 \_N r e c}$ rates could be also related to reduced (although not statistically significant) immobilization of $\mathrm{NH}_{4}^{+}$into labile organic $\mathrm{N}$ $\left(I_{\text {NH4_Nlab }}\right)$ (Fig. 4).

High $\mathrm{NH}_{4}^{+}$additions inhibited mineralization of recalcitrant organic $\mathrm{N}$, resulting in a reduction in gross $\mathrm{N}$ mineralization and immobilization of $\mathrm{NH}_{4}^{+}$into recalcitrant organic N (Figs. 3 and 4). At high $\mathrm{NH}_{4}^{+}$additions, the decline in mineralization of recalcitrant organic $\mathrm{N}$ could be attributed to either reduced fungal biomass, enhanced stabilization of SOM, or both. Whereas a quick recycling of labile organic $\mathrm{N}$ supplies adequate amounts of $\mathrm{NH}_{4}^{+}$, mineralization of recalcitrant requires a depolymerization step which is often carried out by fungal extracellular enzyme (e.g. fungal phenol oxidases and peroxidases of white-rot basidiomycetes) (Carreiro et al., 2000; Frey et al., 2004; Schimel and Bennett, 2004). Our previous field investigations have shown that fungal biomass and fungi to bacteria ratios (Wang et al., 2015) and decomposition of lower-order roots and needles (Kou et al., 2015a, 2015b) exhibited a decreasing trend at high $\mathrm{NH}_{4}^{+}$additions. Moreover, long-term elevated $\mathrm{N}$ input has been found to enhance chemical stabilization of organic matter into recalcitrant compounds that are resistant to microbial decay (Neff et al., 2002; Swanston et al., 2004), thereby potentially impairing fungal metabolism (Maaroufi et al., 2015).

With increasing additions of $\mathrm{NH}_{4}^{+}$, microbial $\mathrm{NH}_{4}^{+}$cycling shifted 
from a state of decoupling (gross $\mathrm{NH}_{4}^{+}$immobilization rates were incomparable to gross $\mathrm{N}$ mineralization rates) to coupling (gross $\mathrm{NH}_{4}^{+}$immobilization rates were comparable to gross $\mathrm{N}$ mineralization rates). However, net gross $\mathrm{NH}_{4}^{+}$production rates (gross $\mathrm{N}$ mineralization rates minus gross $\mathrm{NH}_{4}^{+}$immobilization rates) were similar across treatments. This shows that net gross $\mathrm{NH}_{4}^{+}$production is not a good indicator of soil $\mathrm{N}$ status.

\subsection{The effects of $\mathrm{NH}_{4}^{+}$additions on $\mathrm{NO}_{3}^{-}$production and retention}

Nitrification was almost entirely heterotrophic nitrification, and $\mathrm{NO}_{3}^{-}$was almost retained via immobilization into recalcitrant organic $\mathrm{N}$ at our site (Fig. 3). The dominance of heterotrophic over autotrophic nitrification in $\mathrm{NO}_{3}^{-}$production, and $\mathrm{NO}_{3}^{-}$immobilization over DNRA in $\mathrm{N}$ retention have been observed in a range of tropical/subtropical forest acidic soils $(\mathrm{pH}<5.0)$ with a high soil C: $\mathrm{N}$ ratio (>15) and high fungal biomass (Huygens et al., 2008; Zhang et al., 2013; Zhu et al., 2013). However, we did not observe a significantly positive correlation of heterotrophic nitrification to soil C: N ratio as reported by Zhu et al. (2013). The significantly positive relationship between $\mathrm{NO}_{3}^{-}$immobilization and heterotrophic nitrification $\left(R^{2}=0.59, p=0.015\right)$ might indicate that microbial $\mathrm{NO}_{3}^{-}$immobilization depends directly on heterotrophic nitrification for substrate generation. DNRA rates decreased with increasing gross nitrification rates, suggesting that the importance of DNRA in $\mathrm{N}$ retention might decrease with increasing $\mathrm{NO}_{3}^{-}$ availability. This observation does not support the view of Huygens et al. (2008) that DNRA depends directly on heterotrophic nitrification for substrate generation in forest soils.

In line with our hypothesis, $\mathrm{NH}_{4}^{+}$additions did not stimulate soil $\mathrm{NO}_{3}^{-}$production (autotrophic, heterotrophic and gross nitrification) and weaken soil retention of $\mathrm{NO}_{3}^{-}\left(\mathrm{NO}_{3}^{-}\right.$immobilization and DNRA) in the short term (Fig. 3). Gross $\mathrm{NO}_{3}^{-}$immobilization rates were incomparable to gross $\mathrm{NO}_{3}^{-}$production rates in the control and $\mathrm{NH}_{4}^{+}$ addition plots, suggesting that microbial $\mathrm{NO}_{3}^{-}$cycling was uncoupled in the soil. Net gross $\mathrm{NO}_{3}^{-}$production did not increase with increasing $\mathrm{NH}_{4}^{+}$additions, indicating that increased $\mathrm{NH}_{4}^{+}$additions did not drive microbial $\mathrm{NO}_{3}^{-}$cycling to be more open. Our results are thus contrast to the findings of increased gross nitrification and decreased $\mathrm{NO}_{3}^{-}$immobilization generally observed in tropical forests after N additions (Hall and Matson, 1999; Silver et al., 2005; Corre et al., 2010; Baldos et al., 2015). Our findings suggest that additional $\mathrm{NH}_{4}^{+}$deposition to this subtropical acidic forest will not stimulate additional leaching losses of $\mathrm{NO}_{3}^{-}$.

The lack of responses from heterotrophic nitrification and $\mathrm{NO}_{3}^{-}$ immobilization could be explained by the absence of significant changes in soil C: $\mathrm{N}$ ratio and soil $\mathrm{pH}$ (Table 1 ). Despite the previously observed fungal decline in the high $\mathrm{N}$ addition plots at the same site (Wang et al., 2015), we did not observe a change in heterotrophic nitrification rates in this study. This indicated that fungal biomass may have less of an effect on heterotrophic nitrification rates compared to other ecological factors such as soil C: $\mathrm{N}$ ratio and soil pH (De Boer and Kowalchuk, 2001; Zhu et al., 2013; Zhang et al., 2015). Thus, it remains to be seen whether heterotrophic nitrification and $\mathrm{NO}_{3}^{-}$immobilization will change with decreasing soil $\mathrm{C}$ : $\mathrm{N}$ ratio under long-term $\mathrm{NH}_{4}^{+}$additions.

The small change in ${ }^{15} \mathrm{~N}$ of the $\mathrm{NO}_{3}^{-}$pool after ${ }^{15} \mathrm{NH}_{4} \mathrm{NO}_{3}$ additions indicated that autotrophic nitrification rates in soils were low, and were not controlled by $\mathrm{NH}_{4}^{+}$availability (Figs. S2-10; d). The low autotrophic nitrification rates in this acidic soil could be due to low ammonia $\left(\mathrm{NH}_{3}\right)$ availability (Zhang et al., 2012b; Levy-Booth et al., 2014) and high $\mathrm{NH}_{4}^{+}$immobilization (Vitousek and Reiners, 1982; Huygens et al., 2008). The low autotrophic nitrification potential ensures $\mathrm{N}$ retention, and reduces the risk of $\mathrm{NO}_{3}^{-}$loss under enhanced $\mathrm{NH}_{4}^{+}$deposition. Due to the low autotrophic nitrification capacity, enhanced $\mathrm{NH}_{4}^{+}$deposition may have a low potential to affect autotrophic nitrification rates via acidifying soil (De Boer and Kowalchuk, 2001).

DNRA retained $\mathrm{N}$, but was not an important $\mathrm{N}$ conservation mechanism as suggested in other studies on natural temperate forests (Rütting et al., 2008) or croplands (Chen et al., 2015). DNRA rates were similar across treatments, suggesting that enhanced $\mathrm{NH}_{4}^{+}$deposition would not affect the importance of DNRA in N retention at our site. Silver et al. (2005) even found that deforestation disturbance coupled with fertilization had a minor impact on DNRA in soils. Studies by Zhang et al. (2013) showed that DNRA rates were strikingly similar in mineral soils of 25 forests located in southern (17) and northern (8) China, irrespective of the differences in climate zones, vegetation types (coniferous and broadleaf vegetation), soil properties (e.g. soil $\mathrm{pH}, \mathrm{N}$ status, $\mathrm{C}$ pool, $\mathrm{C}: \mathrm{NO}_{3}^{-}$ ratio) and $\mathrm{N}$ transformations. These observations might point to the fact that DNRA is relatively resistant to disturbances or environmental changes, such as $\mathrm{N}$ deposition (Bengtsson and Bergwall, 2000; Silver et al., 2005).

\section{Conclusions}

Our results show that $\mathrm{NH}_{4}^{+}$deposited to this subtropical forest will not affect gross $\mathrm{NH}_{4}^{+}$immobilization rates, even though gross $\mathrm{N}$ mineralization rates decline. Gross $\mathrm{N}$ mineralization rates declined in the high $\mathrm{NH}_{4}^{+}$addition plots that exhibited reductions in fungal biomass and mineralization of recalcitrant organic N. Our work highlights that at our site, mineralization-immobilization turnover originating from recalcitrant, not labile, organic $\mathrm{N}$ pool was less resistant to disturbance by increasing $\mathrm{NH}_{4}^{+}$additions. In line with our hypothesis, elevated $\mathrm{NH}_{4}^{+}$input did not stimulate soil $\mathrm{NO}_{3}^{-}$ production (heterotrophic, autotrophic and gross nitrification) and weaken soil retention of $\mathrm{NO}_{3}^{-}\left(\mathrm{NO}_{3}^{-}\right.$immobilization and DNRA). Findings from this and other research indicate a general resistance of $\mathrm{NO}_{3}^{-}$production and retention to disturbance by enhanced $\mathrm{NH}_{4}^{+}$ deposition in subtropical/tropical acidic forest soils $(\mathrm{pH}<5)$ with a high soil $\mathrm{C}$ : $\mathrm{N}$ ratio $(>15)$. Our work provides evidence of the dominance of heterotrophic over autotrophic nitrification in $\mathrm{NO}_{3}^{-}$ production, and $\mathrm{NO}_{3}^{-}$immobilization over DNRA in $\mathrm{NO}_{3}^{-}$retention in these soils. In these soils, $\mathrm{NO}_{3}^{-}$immobilization and heterotrophic nitrification might be functionally linked, and autotrophic nitrification might not be controlled by $\mathrm{NH}_{4}^{+}$availability. Thus, changes in heterotrophic nitrification rates under enhanced $\mathrm{NH}_{4}^{+}$deposition could be the major determinant of the direction and magnitude of the change in $\mathrm{NO}_{3}^{-}$production and retention in subtropical/tropical acidic forest soils.

\section{Acknowledgements}

This research is supported by the National Natural Science Foundation of China (Grant No. 31130009; 31570443) and the National Key Project of Scientific and Technical Supporting Program (Grant No. 2013BAC03B03).

\section{Appendix A. Supplementary data}

Supplementary data related to this article can be found at http:// dx.doi.org/10.1016/j.soilbio.2016.06.002.

\section{References}

Arnold, J., Corre, M.D., Veldkamp, E., 2008. Cold storage and laboratory incubation of intact soil cores do not reflect in-situ nitrogen cycling rates of tropical forest soils. Soil Biol. Biochem. 40, 2480-2483.

Baldos, A.P., Corre, M.D., Veldkamp, E., 2015. Response of N cycling to nutrient inputs in forest soils across a 1000-3000 m elevation gradient in the Ecuadorian 
Andes. Ecology 96, 749-761.

Bengtsson, G., Bergwall, C., 2000. Fate of ${ }^{15} \mathrm{~N}$ labelled nitrate and ammonium in a fertilized forest soil. Soil Biol. Biochem. 32, 545-557.

Booth, M.S., Stark, J.M., Rastetter, E., 2005. Controls on nitrogen cycling in terrestrial ecosystems: a synthetic analysis of literature data. Ecol. Monogr. 75, 139-157.

Carreiro, M.M., Sinsabaugh, R.L., Repert, D.A., Parkhurst, D.F., 2000. Microbial enzyme shifts explain litter decay responses to simulated nitrogen deposition. Ecology 81, 2359-2365.

Chen, Z., Ding, W., Xu, Y., Müller, C., Rütting, T., Yu, H., Fan, J., Zhang, J., Zhu, T., 2015 Importance of heterotrophic nitrification and dissimilatory nitrate reduction to ammonium in a cropland soil: evidences from a ${ }^{15} \mathrm{~N}$ tracing study to literature synthesis. Soil Biol. Biochem. 91, 65-75.

Corre, M.D., Beese, F.O., Brumme, R., 2003. Soil nitrogen cycle in high nitrogen deposition forest: changes under nitrogen saturation and liming. Ecol. Appl. 13, 287-298.

Corre, M.D., Brumme, R., Veldkamp, E., Beese, F.O., 2007. Changes in nitrogen cycling and retention processes in soils under spruce forests along a nitrogen enrichment gradient in Germany. Glob. Change Biol. 13, 1509-1527.

Corre, M.D., Veldkamp, E., Arnold, J., Wright, S.J., 2010. Impact of elevated N input on soil N cycling and losses in old-growth lowland and montane forests in Panama. Ecology 91, 1715-1729.

Cox, G.M., Gibbons, J.M., Wood, A.T.A., Craigon, J., Ramsden, S.J., Crout, N.M.J., 2006 Towards the systematic simplification of mechanistic models. Ecol. Model. 198, $240-246$.

Cusack, D.F., Silver, W.L., Torn, M.S., Burton, S.D., Firestone, M.K., 2011. Changes in microbial community characteristics and soil organic matter with nitrogen additions in two tropical forests. Ecology 92, 621-632.

De Boer, W., Kowalchuk, G.A., 2001. Nitrification in acid soils: micro-organisms and mechanisms. Soil Biol. Biochem. 33, 853-866.

Demoling, F., Nilsson, L.O., Baath, E., 2008. Bacterial and fungal response to nitrogen fertilization in three coniferous forest soils. Soil Biol. Biochem. 40, 370-379.

Frey, S.D., Knorr, M., Parrent, J.L., Simpson, R.T., 2004. Chronic nitrogen enrichment affects the structure and function of the soil microbial community in temperate hardwood and pine forests. For. Ecol. Manag. 196, 159-171.

Gao, W., Yang, H., Kou, L., Li, S., 2015. Effects of nitrogen deposition and fertilization on N transformations in forest soils: a review. J. Soils Sediments 15, 863-879.

Galloway, J.N., Townsend, A.R., Erisman, J.W., Bekunda, M., Cai, Z.C., Freney, J.R., Martinelli, L.A., Seitzinger, S.P., Sutton, M.A., 2008. Transformation of the nitrogen cycle: recent trends, questions, and potential solutions. Science 320, $889-892$.

Hall, S.J., Matson, P.A., 1999. Nitrogen oxide emissions after nitrogen additions in tropical forests. Nature 400, 152-155.

Hall, S.J., Matson, P.A., 2003. Nutrient status of tropical rain forests influences soil N dynamics after N additions. Ecol. Monogr. 73, 107-129.

Huygens, D., Boeckx, P., Templer, P.H., Paulino, L., Van Cleemput, O., Oyarzun, C., Müller, C., Godoy, R., 2008. Mechanisms for retention of bioavailable nitrogen in volcanic rainforest soils. Nat. Geosci. 1, 543-548.

Huygens, D., Rütting, T., Boeckx, P., Van Cleemput, O., Godoy, R., Müller, C., 2007. Soil nitrogen conservation mechanisms in a pristine south Chilean Nothofagus forest ecosystem. Soil Biol. Biochem. 39, 2448-2458.

Inselsbacher, E., Wanek, W., Strauss, J., Zechmeister-Boltenstern, S., Müller, C., 2013. A novel ${ }^{15} \mathrm{~N}$ tracer model reveals: plant nitrate uptake governs nitrogen transformation rates in agricultural soils. Soil Biol. Biochem. 57, 301-310.

Janssens, I.A., Dieleman, W., Luyssaert, S., Subke, J.A., Reichstein, M., Ceulemans, R., Ciais, P., Dolman, A.J., Grace, J., Matteucci, G., Papale, D., Piao, S.L., Schulze, E.D., Tang, J., Law, B.E., 2010. Reduction of forest soil respiration in response to nitrogen deposition. Nat. Geosci. 3, 315-322.

Jia, Y., Yu, G., He, N., Zhan, X., Fang, H., Sheng, W., Zuo, Y., Zhang, D., Wang, Q., 2014. Spatial and decadal variations in inorganic nitrogen wet deposition in China induced by human activity. Sci. Rep. 4.

Johnson, D., Krsek, M., Wellington, E.M.H., Stott, A.W., Cole, L., Bardgett, R.D. Read, D.J., Leake, J.R., 2005. Soil invertebrates disrupt carbon flow through fungal networks. Science 309, 1046-1047.

Jones, D.L., Shannon, D., Murphy, D.V., Farrar, J., 2004. Role of dissolved organic nitrogen (DON) in soil N cycling in grassland soils. Soil Biol. Biochem. 36, 749-756.

Koranda, M., Kaiser, C., Fuchslueger, L., Kitzler, B., Sessitsch, A., ZechmeisterBoltenstern, S., Richter, A., 2014. Fungal and bacterial utilization of organic substrates depends on substrate complexity and N availability. Fems Microbiol. Ecol. 87, 142-152.

Kou, L., Chen, W.W., Gao, W.L., Yang, H., Wang, H.M., Li, S.G., 2015a. Effects of mixture of branch order-based roots and nitrogen addition on root decay in a subtropical pine plantation. Biol. Fertil. Soils 51, 947-957.

Kou, L., Chen, W.W., Zhang, X.Y., Gao, W.L., Yang, H., Li, D.D., Li, S.G., 2015b. Differential responses of needle and branch order-based root decay to nitrogen addition: dominant effects of acid-unhydrolyzable residue and microbial enzymes. Plant Soil 394, 315-327.

Levy-Booth, D.J., Prescott, C.E., Grayston, S.J., 2014. Microbial functional genes involved in nitrogen fixation, nitrification and denitrification in forest ecosystems. Soil Biol. Biochem. 75, 11-25.

Liu, X.J., Zhang, Y., Han, W.X., Tang, A.H., Shen, J.L., Cui, Z.L., Vitousek, P., Erisman, J.W., Goulding, K., Christie, P., Fangmeier, A., Zhang, F.S., 2013. Enhanced nitrogen deposition over China. Nature 494, 459-462.

Müller, C., Rütting, T., Kattge, J., Laughlin, R.J., Stevens, R.J., 2007. Estimation of parameters in complex ${ }^{15} \mathrm{~N}$ tracing models by Monte Carlo sampling. Soil Biol.
Biochem. 39, 715-726.

Müller, C., Stevens, R.J., Laughlin, R.J., 2004. A ${ }^{15} \mathrm{~N}$ tracing model to analyse $\mathrm{N}$ transformations in old grassland soil. Soil Biol. Biochem. 36, 619-632.

Maaroufi, N.I., Nordin, A., Hasselquist, N.J., Bach, L.H., Palmqvist, K., Gundale, M.J., 2015. Anthropogenic nitrogen deposition enhances carbon sequestration in boreal soils. Glob. Change Biol. 21, 3169-3180.

Mo, J., Zhang, W., Zhu, W., Gundersen, P., Fang, Y., Li, D., Wang, H., 2008. Nitrogen addition reduces soil respiration in a mature tropical forest in southern China. Glob. Change Biol. 14, 403-412.

Myrold, D.D., Tiedje, J.M., 1986. Simultaneous estimation of several nitrogen-cycle rates using ${ }^{15} \mathrm{~N}$ - theory and application. Soil Biol. Biochem. 18, 559-568.

Neff, J.C., Townsend, A.R., Gleixner, G., Lehman, S.J., Turnbull, J., Bowman, W.D., 2002. Variable effects of nitrogen additions on the stability and turnover of soil carbon. Nature 419, 915-917.

Paterson, E., 2003. Importance of rhizodeposition in the coupling of plant and microbial productivity. Eur. J. Soil Sci. 54, 741-750.

Perakis, S.S., Compton, J.E., Hedin, L.O., 2005. Nitrogen retention across a gradient of ${ }^{15} \mathrm{~N}$ additions to an unpolluted temperate forest soil in Chile. Ecology 86, 96-105.

Rütting, T., Huygens, D., Müller, C., Cleemput, O., Godoy, R., Boeckx, P., 2008. Functional role of DNRA and nitrite reduction in a pristine south Chilean Nothofagus forest. Biogeochemistry 90, 243-258.

Rütting, T., Müller, C., 2007. ${ }^{15} \mathrm{~N}$ tracing models with a Monte Carlo optimization procedure provide new insights on gross $\mathrm{N}$ transformations in soils. Soil Biol. Biochem. 39, 2351-2361.

Rütting, T., Clough, T.J., Mueller, C., Lieffering, M., Newton, P.C.D., 2010. Ten years of elevated atmospheric carbon dioxide alters soil nitrogen transformations in a sheep-grazed pasture. Glob. Change Biol. 16, 2530-2542.

Schimel, J.P., Bennett, J., 2004. Nitrogen mineralization: challenges of a changing paradigm. Ecology 85, 591-602.

Silver, W.L., Herman, D.J., Firestone, M.K., 2001. Dissimilatory nitrate reduction to ammonium in upland tropical forest soils. Ecology 82, 2410-2416.

Silver, W.L., Thompson, A.W., Reich, A., Ewel, J.J., Firestone, M.K., 2005. Nitrogen cycling in tropical plantation forests: potential controls on nitrogen retention. Ecol. Appl. 15, 1604-1614.

Swanston, C., Homann, P., Caldwell, B., Myrold, D., Ganio, L., Sollins, P., 2004. Longterm effects of elevated nitrogen on forest soil organic matter stability. Biogeochemistry 70, 229-252.

Templer, P.H., Mack, M.C., Chapin, F.S., Christenson, L.M., Compton, J.E., Crook, H.D., Currie, W.S., Curtis, C.J., Dail, D.B., D’Antonio, C.M., Emmett, B.A., Epstein, H.E., Goodale, C.L., Gundersen, P., Hobbie, S.E. Holland, K. Hooper, D.U., Hungate, B.A., Lamontagne, S., Nadelhoffer, K.J., Osenberg, C.W., Perakis, S.S., Schleppi, P., Schimel, J., Schmidt, I.K., Sommerkorn, M., Spoelstra, J., Tietema, A., Wessel, W.W., Zak, D.R., 2012. Sinks for nitrogen inputs in terrestrial ecosystems: a meta-analysis of N-15 tracer field studies. Ecology 93, 1816-1829.

Venterea, R.T., Groffman, P.M., Verchot, L.V., Magill, A.H., Aber, J.D., 2004. Gross nitrogen process rates in temperate forest soils exhibiting symptoms of nitrogen saturation. For. Ecol. Manag. 196, 129-142.

Vitousek, P.M., Reiners, W.A., 1982. A comparative analysis of potential nitrification and nitrate mobility in forest ecosystems. Ecol. Monogr. 52, 155-177.

Wang, Y., Cheng, S., Fang, H., Yu, G., Xu, X., Xu, M., Wang, L., Li, X., Si, G., Geng, J., $\mathrm{He}, \mathrm{S} ., 2015$. Contrasting effects of ammonium and nitrate inputs on soil CO2 emission in a subtropical coniferous plantation of southern China. Biol. Fertil. Soils 51, 815-825.

Wang, Y., Wang, Z.-L., Wang, H., Guo, C., Bao, W., 2012. Rainfall pulse primarily drives litterfall respiration and its contribution to soil respiration in a young exotic pine plantation in subtropical China. Can. J. For. Research-Revue Can. De Recherche For. 42, 657-666.

Wen, X.F., Wang, H.M., Wang, J.L., Yu, G.R., Sun, X.M., 2010. Ecosystem carbon exchanges of a subtropical evergreen coniferous plantation subjected to seasonal drought, 2003-2007. Biogeosciences 7, 357-369.

Zhan, X., Yu, G., He, N., Fang, H., Jia, B., Zhou, M., Wang, C., Zhang, J., Zhao, G., Wang, S., Liu, Y., Yan, J., 2014. Nitrogen deposition and its spatial pattern in main forest ecosystems along north-south transect of eastern China. Chin. Geogr. Sci. 24, 137-146.

Zhang, J.B., Cai, Z.C., Cheng, Y., Zhu, T.B., 2009. Denitrification and total nitrogen gas production from forest soils of Eastern China. Soil Biol. Biochem. 41, 2551-2557.

Zhang, J.B., Cai, Z.C., Zhu, T.B., Yang, W.Y., Müller, C., 2013. Mechanisms for the retention of inorganic $\mathrm{N}$ in acidic forest soils of southern China. Sci. Rep. 3.

Zhang, J.B., Müller, C., Cai, Z.C., 2015. Heterotrophic nitrification of organic N and its contribution to nitrous oxide emissions in soils. Soil Biol. Biochem. 84, 199-209.

Zhang, J.B., Zhu, T.B., Cai, Z.C., Qin, S.W., Müller, C., 2012a. Effects of long-term repeated mineral and organic fertilizer applications on soil nitrogen transformations. Eur. J. Soil Sci. 63, 75-85.

Zhang, L.M., Hu, H.W., Shen, J.P., He, J.Z., 2012b. Ammonia-oxidizing archaea have more important role than ammonia-oxidizing bacteria in ammonia oxidation of strongly acidic soils. Isme J. 6, 1032-1045.

Zhao, W., Cai, Z.C., Xu, Z.H., 2007. Does ammonium-based N addition influence nitrification and acidification in humid subtropical soils of China? Plant Soil 297, 213-221.

Zhu, T.B., Meng, T.Z., Zhang, J.B., Yin, Y.F., Cai, Z.C., Yang, W.Y., Zhong, W.H., 2013. Nitrogen mineralization, immobilization turnover, heterotrophic nitrification, and microbial groups in acid forest soils of subtropical China. Biol. Fertil. Soils 49, 323-331. 